\title{
Eugenia Klotzschiana O. Berg Fruits as New Sources of Nutrients: Determination of their Bioactive Compounds, Antioxidant Activity and Chemical Composition
}

Nárgella Silva Carneiro ${ }^{1}$
https://orcid.org/0000-0001-5513-0134 $^{1}$

Cássia Cristina Fernandes Alves ${ }^{1}$

https://orcid.org/0000-0003-2004-3166

Caroline Cagnin ${ }^{1}$

https://orcid.org/0000-0002-9961-2589

Celso Martins Belisario ${ }^{1}$

https://orcid.org/0000-0001-8693-6384

Marco Antônio Pereira da Silva ${ }^{1}$

https://orcid.org/0000-0002-3875-1104

Mayker Lazaro Dantas Miranda ${ }^{2}$

https://orcid.org/0000-0003-4689-572X

Josemar Gonçalves de Oliveira Filho ${ }^{1}$

https://orcid.org/0000-0001-9755-7128

José Milton Alves ${ }^{1}$

https://orcid.org/0000-0002-2477-206X

Paulo Sérgio Pereira ${ }^{1}$

Fabiano Guimarães Silva ${ }^{1}$

https://orcid.org/0000-0003-4908-2265

Mariana Buranelo Egea ${ }^{*}$

https://orcid.org/0000-0001-7589-2718

${ }^{1}$ Goiano Federal Institute of Education, Science and Technology, Rio Verde Campus, Rio Verde, Brazil; ${ }^{2}$ Federal Institute of Education, Science and Technology South of Minas, Pouso Alegre Campus, Pouso Alegre, MG, Brazil

Received: 2017.08.31; Accepted: 2019.03.30.

* Correspondence: mariana.egea@ifgoiano.edu.br; Tel.: +55-64-36205600 (M.B.E) 


\section{HIGHLIGHTS}

- The Eugenia klotzschiana fruits have high fibre content.

- The iron content in the Cerrado pear is 55-times higher than common pear.

- The Cerrado pear presented high pulp yield.

Abstract: The Cerrado is one of the world's biodiversity hotspots and Brazil's second largest biome. Many native species of the Brazilian Cerrado provide fruits that have unique sensory characteristics and high nutritional value. This study aimed at characterizing the pulp of Eugenia klotzschiana O. Berg, concerning its proximal composition, bioactive compound content and antioxidant activity. The pulp under study had high moisture $(89.47$ $\left.\mathrm{g} \mathrm{kg}^{-1}\right)$ and caloric $\left(96.07 \mathrm{kcal} \mathrm{kg}^{-1}\right)$ values whereas its contents of protein $\left(0.59 \mathrm{~g} \mathrm{~kg}^{-1}\right)$ and lipids $\left(2.35 \mathrm{~g} \mathrm{~kg}^{-1}\right)$ were low. The cerrado pear pulp also had high iron content (16.5 mg kg ${ }^{-1}$ ) and dietary fiber $\left(6.45 \mathrm{~g} \mathrm{~kg}^{-1}\right)$, besides $0.034-0,055 \mathrm{mg} \mathrm{kg}^{-1}$ carotenoids, $8.66 \mathrm{mg} \mathrm{kg}^{-1}$ ascorbic acid and $0.66 \mathrm{mg} \mathrm{kg}^{-1}$ total chlorophyll. Total phenolic compounds (333.41-566.33 $\mathrm{mg}$ EAG kg-1) and flavonoids (225-50 mg EQ kg-1) were found by extraction methods named Method 1 (water) and Method 2 (acetone+methanol), respectively. Thus, the cerrado pear can be an alternative to improving nutrient intake and to providing sustainable use of the native flora in the Cerrado.

Keywords: Cerrado pear; Nutrients; Flavonoids; Antioxidant capacity.

\section{INTRODUCTION}

The Cerrado is one of the world's biodiversity hotspots and Brazil's second largest biome, since it stretches over 2 million $\mathrm{km}^{2}$ in Latin America and covers $22 \%$ of the Brazilian territory. With regard to its biological diversity, this region has been recognized as the richest savanna in the world because it has about 10,000 cataloged native plant species [1]. Expansion of agriculture and the use of modern technology in the Cerrado have generated undeniable socioeconomic benefits. However, areas that result from poor soil management with considerable erosion or invasion of exotic species can be found in the Cerrado. Around $55 \%$ of the original area was deforested or transformed by human action. In addition, the Cerrado has great biodiversity and endangered species of fauna and flora.

Many native species of the Brazilian Cerrado provide fruits that have unique sensory characteristics (color, aroma and flavor) and high nutritional value, regarding their levels of sugars, proteins, vitamins, minerals and compounds with high antioxidant activity. Among compounds that have functional properties in food, substances with antioxidant activities have received significant attention because they protect the human body against oxidative stress and prevent a number of chronic degenerative disorders [2]. Although these native fruits have high nutritional value, their economic aspect is undervalued; they have been consumed by the local population but still need to play more important roles in the industry and marketing [3-4]. Thus, studies have been conducted in order to characterize the native fruits of the Cerrado to promote appreciation of the importance of these products and encourage sustainable development [3, 5-6].

The cerrado pear (Eugenia klotzschiana O. Berg.), also known as pera-do-campo and cabacinha-do-campo, which belongs to the Myrtaceae family, is a native fruit of the Brazilian Cerrado and unknown to the food industry. The plant is a small 1-2-meter high shrub, with variable-sized fruits, which are yellow - when they are ripe - and have soft, astringent and sour pulp (due to its high acidity) [7-8]. The cerrado pear has been consumed fresh and used for producing jelly. Nevertheless, there is little knowledge about the cerrado pear due to its 
restricted geographical distribution and the great difficulty in using its seeds directly for planting [9].

In the literature, few studies that describe the complete characterization of the pulp of $E$. klotzschiana O. Berg. fruits were found. This study aimed at characterizing the pulp of $E$. klotzschiana O. Berg., a native fruit of the Cerrado biome, concerning its chemical composition (proximal and mineral compositions), physical characteristics, bioactive compound content and antioxidant activity.

\section{MATERIAL AND METHODS}

\section{Standards}

Reagents (Folin \& Ciocalteu's phenol reagent, ABTS 2,2'-Azino-bis (3-ethylbenzthiazoline-6-sulfonic acid), DPPH (2,2-diphenyl-1-picrylhydrazyl), TPTZ (2,4,6-Tris(2-pyridyl)-s-triazine) and BHT (3,5-Di-tert-4-butylhydroxytoluene) and standards (trolox (6-hydroxy-2,5,7,8-tetramethylchroman-2-carboxylic acid), quercetin (98\% HPLC grade), gallic acid and glucose) were purchased from Sigma (Steinheim, Germany). Other reagents, i. e., sodium carbonate, chloroform, hexane, copper sulphate, sodium selenite, sodium sulfate, boric acid, 3,5 dinitrosalicylic acid, methyl red and potassium persulfate (Neon, São Paulo, Brazil); aluminum chloride hexahydrate, hydrochloric acid, sulfuric acid, acetone and glacial acetic acid (Vetec, Rio de Janeiro, Brazil); ethyl alcohol (Fmaia, São Paulo, Brazil); methyl alcohol, oxalic acid, sodium phosphate, ascorbic acid and 2,6-dichlorophenolindophenol (Dinâmica, São Paulo, Brazil); ferric chloride and ferrous sulphate (Alphatec SA, Rio de Janeiro, Brazil); and sodium nitrite (Synth, São Paulo, Brazil) were analytical grade. Enzymes were amylase, protease and amyloglucosidase.

\section{Raw Material}

Cerrado pears (E. klotzschiana O. Berg) were collected in areas of native vegetation, typical of the Cerrado, in Portelândia ( $17^{\circ} 23^{\prime} \mathrm{S}$ and $\left.52^{\circ} 38^{\prime} \mathrm{W}\right)$, Goiás, Brazil, in the harvest season (from December 2014 to January 2015). Morphologically perfect and completely mature fruits were washed - to have all dirt removed - and dried at room temperature. The cerrado pear was considered ripe when its skin was yellow. This color was related to the luminosity $\left(\mathrm{L}^{*}\right)$, ranging from 40.34 to 40.68 , to the ratio of red to green $\left(\mathrm{a}^{*}\right)$, ranging from 12.64 to 13.96 and to the ratio of yellow to blue $\left(b^{*}\right)$, ranging from 25.72 to 26.84 , in agreement with the CIE system (Commission Internationale de l'Eclairage). Cerrado pears were frozen and the pulp and skin were separated manually from the seeds and homogenized immediately before analysis. The color of the cerrado pear pulp was related to the luminosity $\left(\mathrm{L}^{*}\right)$, ranging from 56.70 to 65.20 , to the ratio of red to green $\left(\mathrm{a}^{*}\right)$, ranging from 3.18 to 4.74 and to the ratio of yellow to blue $\left(b^{*}\right)$, ranging from 33.72 to 37.48 , in agreement with the CIE system.

\section{Physical and chemical characterization}

Individual measurements of mass, transverse and longitudinal diameters were carried out in 20 fruits by a digital caliper rule (Mitutoyo, São Paulo, Brazil). Fruit mass (FM), pulp mass (pulp, PM) and residue mass (RM) were obtained by direct individual weighing on a semi-analytical balance (Shimadzu, São Paulo, Brazil). Pulp yield was calculated by the formula $(P M / F M) \times 100$. Chemical analyses were performed in 4 repetitions. Values of titratable acidity, soluble solids and $\mathrm{pH}$ [10]; moisture, ash, protein, lipids and total dietary fiber [11] were determined. Carbohydrates were calculated by subtraction, by the following formula: $100-(\%$ moisture $+\%$ lipids $+\%$ protein $+\%$ total dietary fiber $+\%$ ash $)$. The total energy value was estimated by considering the conversion factors of $4 \mathrm{kcal} \mathrm{g}^{-1}$ protein or carbohydrate and $9 \mathrm{kcal} \mathrm{g}^{-1}$ lipid [12]. Total sugar contents (reducing and non-reducing ones) were determined in agreement with Miller [13]. Results were expressed as $\mathrm{g}$ glicose $\mathrm{kg}^{-1}$ fresh matter (FM). Mineral contents were evaluated in crushed and homogenized samples, which were dried in an oven at $105^{\circ} \mathrm{C}$ and digested in $\mathrm{HNO}_{3}$ and $\mathrm{HClO}_{4}$, as described by 
Malavolta [14]. Quantification of minerals found in the samples, i. e., calcium (Ca), magnesium (Mg), manganese (Mn), copper $(\mathrm{Cu})$, iron (Fe) and zinc $(\mathrm{Zn})$, was carried out by dual beam atomic absorption spectroscopy GBC-XPLORAA-2 (GBC, Lakeside, Australia). Potassium (K) quantification was determined by a photoelectric flame photometer B-462. The phosphorus $(\mathrm{P})$ was determined by colorimetry (molecular absorption spectrophotometry).

\section{Bioactive compounds}

Total carotenoid contents were determined according to Nagata and Yamashita [15]. Two g pulp was extracted in $20 \mathrm{~mL}$ acetone:hexane (4:6) in the dark and then centrifuged for 3 minutes at $20^{\circ} \mathrm{C}$ at $15.000 \mathrm{rpm}$ (ITR model 8BT, Med. Instruments, Warsaw, Mazowieckie, Poland). Afterwards, the extract was filtered through Whatman filter paper No. 4 and absorbance was measured at $453 \mathrm{~nm}, 505 \mathrm{~nm}, 645 \mathrm{~nm}$ and $663 \mathrm{~nm}$. Results were expressed as $\mathrm{mg} \beta$-carotene per $\mathrm{kg}^{-1} \mathrm{FM}$ and $\mathrm{mg}$ lycopene per $\mathrm{kg}^{-1} \mathrm{FM}$. Total chlorophyll contents were determined according to Arnon [16]. One g pulp was homogenized in $30 \mathrm{~mL}$ acetone:water $(80: 20, \mathrm{v} / \mathrm{v})$ and filtered through Whatman No. 4. The volume of the mixture was adjusted to $50 \mathrm{~mL}$ and absorbance was measured at 645 and $663 \mathrm{~nm}$. Total chlorophyll was calculated by the following equation: $20.2 \cdot A_{645}+8.02 \cdot A_{663}$, where $\mathrm{A}_{645}$ is the absorbance at $645 \mathrm{~nm}$ and $A_{663}$ is the absorbance at $663 \mathrm{~nm}$. Results were expressed as $\mathrm{mg}$ per $\mathrm{kg}^{-1} \mathrm{FM}$. The ascorbic acid analysis was performed by the official method modified by Benassi and Antunes [17]. Five g fresh pulp was homogenized in $50 \mathrm{~mL}$ acid oxalic $2 \%$ and filtered through Whatman No. 4. Ten-mL aliquots were titrated with $0.2 \%$ dichlorophenol-indophenol. Results were expressed as milligrams of reduced AA per $\mathrm{kg}^{-1}$ fresh weight (FW). In order to determine total phenolic compounds, total flavonoids and antioxidant activity (DPPH, ABTS and FRAP methods), two extraction methods were compared. In Method 1, $20 \mathrm{~g}$ fresh pulp was homogenized in $100 \mathrm{~mL}$ water and filtered through Whatman No. 4 [18]. In Method 2, the procedure developed by Larrauri, Rupérez, and Saura-Calixto [19], with modifications, was employed as follows: $20 \mathrm{~g}$ fresh pulp was extracted sequentially with $40 \mathrm{~mL}$ methanol:water $(50: 50, \mathrm{v} / \mathrm{v})$ at room temperature for $1 \mathrm{~h}$ and filtered through Whatman No. 4. The supernatant was recovered and extracted with 40 $\mathrm{mL}$ acetone:water $(70: 30, \mathrm{v} / \mathrm{v})$ at room temperature for $60 \mathrm{~min}$ and filtered. Methanol and acetone extracts were combined and distilled water was added to make up the volume to $100 \mathrm{~mL}$. Total flavonoid contents were determined by colorimetry, according to Subhasree et al. [20]. In the process, $250 \mu \mathrm{l}$ extract was added to $1.5 \mathrm{~mL}$ distilled water and $150 \mu \mathrm{l} 5 \%$ $(\mathrm{m} / \mathrm{v}) \mathrm{NaNO}_{2}$. After $5 \mathrm{~min}, 300 \mu \mathrm{l} 10 \%(\mathrm{~m} / \mathrm{v}) \mathrm{AlCl}_{3} \cdot 6 \mathrm{H}_{2} \mathrm{O}$ was added to the mixture, homogenized and left for 6 minutes at room temperature $\left(25^{\circ} \mathrm{C}\right)$. Afterwards, $1.0 \mathrm{~mL} 1 \mathrm{M}$ $\mathrm{NaOH}$ was added to the mixture and the volume was adjusted to $5 \mathrm{~mL}$. Absorbance of the mixture was measured at $510 \mathrm{~nm}$. Quercetin was used as standard and results were expressed as g quercetin per $\mathrm{kg}^{-1}$ fresh fruit.

\section{Total phenolic compounds and antioxidant activity}

Total phenolic compounds were determined by the Folin-Ciocalteu assay, based on Waterhouse [21]. Results were expressed as mg gallic acid equivalent $\mathrm{kg}^{-1} \mathrm{FM}\left(\mathrm{EAG} \mathrm{kg}^{-1}\right)$. An aliquot of crude extracts $(100 \mu \mathrm{L})$ was mixed with $500 \mu \mathrm{L}$ Folin-Ciocalteau reagent. Then, $7.4 \mathrm{~mL}$ water was added to it. After $1 \mathrm{~min}$, a sodium carbonate solution (15\%) was also added. After a 120-min reaction in the dark at room temperature, absorbance of the mixture was measured at $720 \mathrm{~nm}$. The antioxidant activity was determined in crude extracts (Methods 1 and 2) by the ABTS, DPPH and FRAP methods. In the DPPH assay [22], $100 \mu \mathrm{L}$ crude extract was added to $3.9 \mathrm{~mL} 60 \mu \mathrm{M}$ 2,2-diphenyl-1-picrylhydrazyl (DPPH) methanol solution. After a 30-min incubation period at room temperature, in the dark, absorbance was measured at $515 \mathrm{~nm}$. The antioxidant capacity was expressed as the concentration of antioxidant required to reduce the original amount of free radicals by $50 \%\left(E_{50}\right)$. In the ABTS assay, ABTS radical cations (ABTS ${ }^{\circ}$ ) were generated by reacting $5 \mathrm{~mL}$ aqueous ABTS solution $(7 \mathrm{mM})$ and $88 \mu \mathrm{L}$ potassium persulfate solution $(140 \mathrm{mM})$ to make up the final concentration to $2.45 \mathrm{mM}$ ). The mixture, which was left in the dark for $14 \mathrm{~h}$ at room 
temperature, was then diluted with ethanol to obtain absorbance of $0.7 \pm 0.02$ at $734 \mathrm{~nm}$. Crude extracts $(30 \mu \mathrm{L})$ were added to $3 \mathrm{~mL}$ ABTS radical solution in the dark and absorbance was measured at $734 \mathrm{~nm}$ after $6 \mathrm{~min}$ [23]. Antioxidant capacity of each sample was estimated by the FRAP assay, in agreement with the procedure described in the literature [24] with modifications. In the assay, $2.7 \mathrm{~mL}$ of freshly prepared FRAP reagent (TPTZ, $\mathrm{FeCl}_{3}$ and acetate buffer) at $37^{\circ} \mathrm{C}$ was mixed with $90 \mu \mathrm{L}$ fruit extract and $270 \mu \mathrm{L}$ distilled water. A blank containing the FRAP reagent was used as reference and absorbance was determined at $595 \mathrm{~nm}$ after $30 \mathrm{~min}$. Aqueous solutions of Fe (II) concentrations ranging from 100 to $1500 \mu \mathrm{M}\left(\mathrm{Fe}_{2} \mathrm{SO}_{4}\right)$ were used for calibration.

\section{Statistical analysis}

Assays were performed in triplicate for each sample. Results were expressed as mean values \pm standard deviation (SD). To prove significant differences between both extraction methods, the statistical analysis of the data was carried out by one-way analysis of variance, followed by the $\mathrm{T}$ test at $95 \%$ probability. To determine whether the bioactive compounds contributed to the antioxidant capacity, Pearson's correlation coefficients were calculated at $1 \%$ and $5 \%$ probability by the Student's $t$ test for all variables.

\section{RESULTS}

The cerrado pear has a round base which decreases in longitudinal direction (piriformis format). Its skin is dark yellow and velvety. Inside, a yellow juicy pulp and cream-colored seeds can be found (Fig 1).

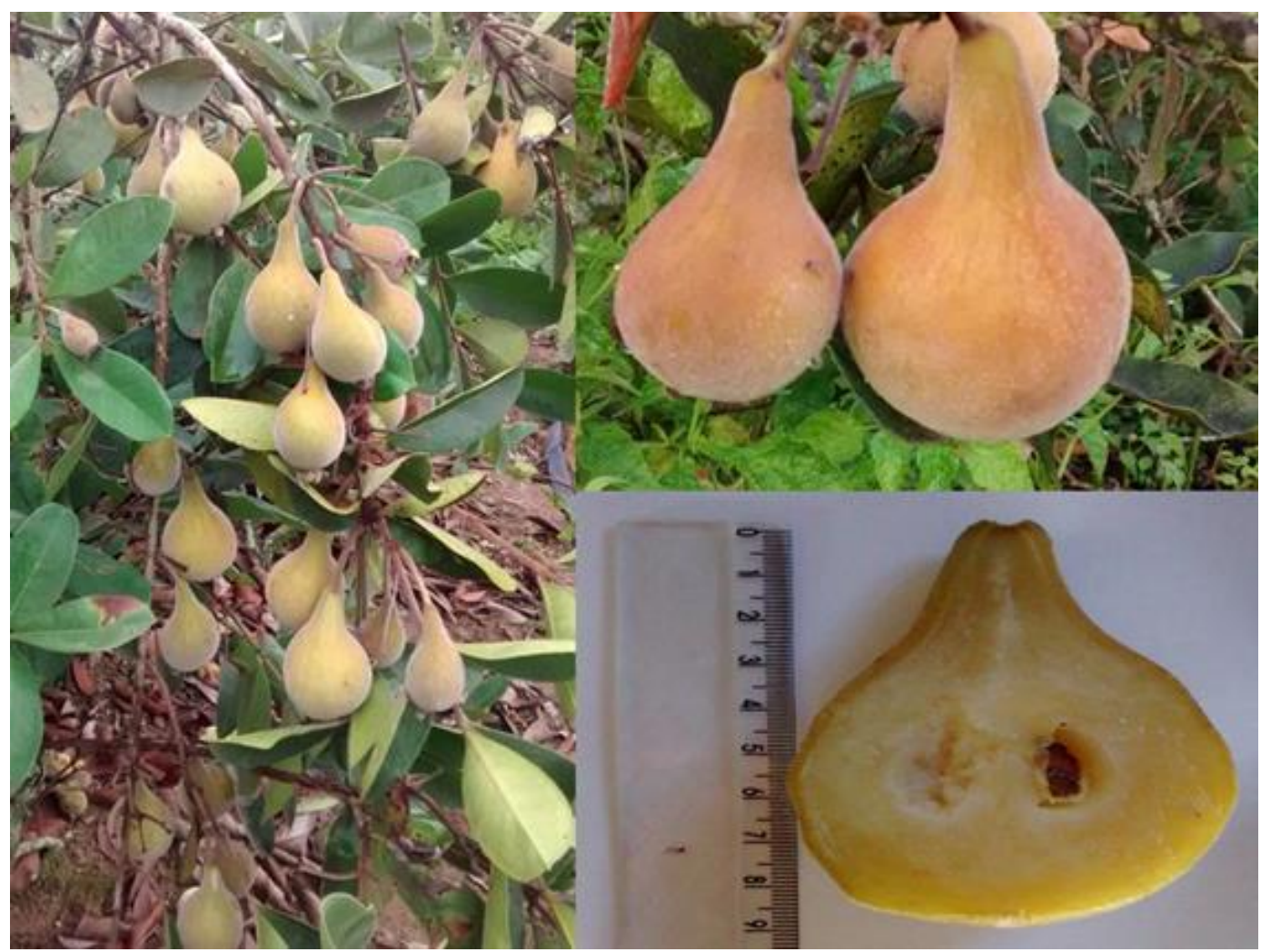

Figure 1. Photographic representation of cerrado pears (E. klotzschiana O.Berg) 
The Table 1 showed physical characteristics of cerrado pear. Total titratable acidity (TTA) of the cerrado pear was $2.07 \pm 0.01 \mathrm{~g}$ citric acid kg ${ }^{-1}$, its $\mathrm{pH}$ was $3.00 \pm 0.00$ and total soluble solid (TSS) content was $6.00 \pm 0.10^{\circ}$ Brix.

Table 1. Physical characteristics of the cerrado pear (E. klotzschiana O. Berg) from the Cerrado (Portelândia, Goiás, Brazil)

\begin{tabular}{cccc}
\hline Variables & Mean $^{\mathrm{a}} \pm \mathrm{SD}^{\mathrm{b}}$ & \multicolumn{2}{c}{ Amplitude } \\
& & Minimum & Maximum \\
\hline Longitudinal diameter $(\mathrm{cm})$ & $8.96 \pm 0.87$ & 4.8 & 10.3 \\
Transverse diameter $(\mathrm{cm})$ & $5.95 \pm 0.59$ & & 6.7 \\
Mass $(\mathrm{g})$ & & 74.42 & 172.53 \\
Fruit & $101.73 \pm 29.24$ & 24.20 & 72.29 \\
Residue & $38.34 \pm 13.90$ & 49.52 & 100.24 \\
Pulp & $67.75 \pm 15.84$ & 58.10 & 67.17 \\
Pulp yield $\left(\mathrm{g} \mathrm{kg}^{-1}\right)$ & $64.35 \pm 3.16$ & \\
\multicolumn{3}{c}{ a Mean of 20 fruits } \\
\end{tabular}

Table 2 shows the chemical characteristics of the cerrado pear pulp. The pulp had high moisture content $\left(89.47 \mathrm{~g} \mathrm{~kg}^{-1}\right)$ which makes the fruit lie within the class of fleshy and succulent tropical fruits. The fragility of the skin makes the cerrado pear highly susceptible to enzymatic and microbial deterioration, a fact that makes its preservation difficult.

Table 2. Chemical characteristics $\left(\mathrm{g} \mathrm{kg}^{-1}\right)$ and total energy value $\left(\mathrm{kcal} \mathrm{kg}^{-1}\right)$ of the cerrado pear (E. klotzschiana O. Berg) from the Cerrado (Portelândia, Goiás, Brazil).

\begin{tabular}{cc}
\hline $\begin{array}{c}\text { Variables (expressed as fresh } \\
\text { matter }- \text { FM) }\end{array}$ & $\begin{array}{c}\text { Means } \pm \text { Standard } \\
\text { deviation }\end{array}$ \\
\hline Moisture & $89.47 \pm 0.29$ \\
Ash & $0.04 \pm 0.00$ \\
Protein & $0.59 \pm 0.01$ \\
Lipids & $2.35 \pm 0.14$ \\
Carbohydrates & $7.50 \pm 0.40$ \\
Dietary fiber & 6.45 \\
Soluble fiber & 1.36 \\
Insoluble fiber & 5.09 \\
Caloric value & $96.07 \pm 2.33$ \\
Total sugars & $1.35 \pm 0.03$ \\
Reducing sugars & $1.15 \pm 0.01$ \\
\hline
\end{tabular}

Values of total, reducing and non-reducing sugars were $1.35,1.15$ and $0.2 \mathrm{~g} \mathrm{~kg}^{-1}$, respectively, similar to the one found for murici $\left(1.83 \mathrm{~g} \mathrm{~kg}^{-1}\right)$. These attributes affect consumers' acceptability directly [6]

Mineral composition of the cerrado pear pulp is shown in Table 3. Among the minerals evaluated in this work were the quantity of iron, manganese, copper, potassium, phosphorus, magnesium and zinc. 
Table 3. Mineral contents of the cerrado pear (E. klotzschiana O. Berg) (Portelândia, Goiás, Brazil) and its contribution to dietary reference intake (\%DRI).

\begin{tabular}{ccc}
\hline Minerals $\left(\mathrm{mg} 100 \mathrm{~g}^{-1} \mathrm{FM}\right)$ & Cerrado pear & \%DRI \\
\hline Potassium & 625.00 & 13.29 \\
Phosphorus & 131.00 & 18.71 \\
Calcium & 140.00 & 1.16 \\
Magnesium & 54.00 & 12.85 \\
Iron & 16.50 & 206.25 \\
Manganese & 1.10 & 47.82 \\
Copper & 0.57 & 63.33 \\
Zinc & 1.61 & 14.36
\end{tabular}

Since there is no information available in the literature regarding bioactive compounds, phenolic compound contents and antioxidant capacity of the cerrado pear, reference data on other small fruits were used by this study. Table 4 shows ascorbic acid, total chlorophyll and total carotenoids in $\beta$-caroteno and licopeno.

Table 4. Bioactive compounds ( $\mathrm{mg} \mathrm{kg}^{-1}$ fresh matter) of the cerrado pear (E. klotzschiana O. Berg) from the Cerrado (Portelândia, Goiás, Brazil)

\begin{tabular}{cc}
\hline Variables & Means \pm Standard deviation \\
\hline Total chorophyll & $0.660 \pm 0.00$ \\
Total carotenoids ( $\beta$-caroteno) & $0.034 \pm 0.01$ \\
Total carotenoids (licopeno) & $0.055 \pm 0.01$ \\
Ascorbic acid & $8.660 \pm 0.07$ \\
\hline
\end{tabular}

Table 5 shows results of total phenolic compounds (TPC), total flavonoids and antioxidant activity of the cerrado pear pulp by both extraction methods under study.

In this study, TPC content extracted by Method 2 (566 mg EAG kg-1) was significantly higher than the one found by Method 1 (333 mg EAG kg-1). Concerning flavonoid contents, Method 2 (550 mg EQ kg-1) was significantly more efficient than Method 1 because its extraction was 2-fold higher than the one of the latter (225 mg EQ kg-1).

In the DPPH assay, low $\mathrm{EC}_{50}$ value represented high antioxidant activity. The cerrado pear pulp had low $\mathrm{EC}_{50}$ in both extractions $\left(0.74 \mu \mathrm{g} \mathrm{mL}^{-1}\right.$ and $0.78 \mu \mathrm{g} \mathrm{mL}^{-1}$ in Method 1 and Method 2, respectively). In this study, $\mathrm{EC}_{50}$ of the cerrado pear was higher than the ones reported for other Cerrado native fruits, such as cagaita $\left(14.15 \mu \mathrm{g} \mathrm{mL}^{-1}\right)$ [5].

Calculation of the antioxidant activity was equivalent to the edible part of the fruit $(0.08$ and $0.09 \mathrm{~g}$ pulp in Method 1 and Method 2, respectively) to neutralize $1 \mathrm{~g} \mathrm{DPPH}$. The cerrado pear had 220.80 and $319.20 \mu \mathrm{mol} \mathrm{TE} \mathrm{g}{ }^{-1}$ in the ABTS assay in Method 1 and Method 2, respectively. 
Table 5. Total flavonoids, total phenolic compounds and antioxidant activity of the cerrado pear pulp (E. klotzschiana O. Berg) from the Cerrado (Portelândia, Goiás, Brazil)

\begin{tabular}{lcc}
\hline \multicolumn{1}{c}{ Variables } & Method 1 & Method 2 \\
\hline Total phenolic compounds $\left(\mathrm{mg} \mathrm{EAG} \mathrm{kg}^{-1}\right)$ & $333.41 \pm 0,80^{\mathrm{b}}$ & $566.33 \pm 0.98^{\mathrm{a}}$ \\
Total flavonoids mg. EQ kg $\left.{ }^{-1} \mathrm{FM}\right)$ & $225.00 \pm 0.10^{\mathrm{b}}$ & $550.00 \pm 0.74^{\mathrm{a}}$ \\
Antioxidant activity - DPPH $\left(\mathrm{EC}_{50} \mu \mathrm{g} \mathrm{mL}^{-1}\right)$ & $0.74^{\mathrm{a}}$ & $0.78^{\mathrm{a}}$ \\
Antioxidant activity - DPPH $\left(\mathrm{g} \mathrm{g}^{-1} \mathrm{DPPH}\right)$ & $0.08^{\mathrm{a}}$ & $0.09^{\mathrm{a}}$ \\
Antioxidant activity - ABTS $\left(\mu \mathrm{mol} \mathrm{TE}^{-1} \mathrm{FM}\right)$ & $220.80^{\mathrm{a}}$ & $319.20^{\mathrm{b}}$ \\
Antioxidant activity - FRAP $\left(\mu \mathrm{M} \mathrm{Fe} \mathrm{g}^{-1} \mathrm{FM}\right)$ & $0.47 \pm 0.01^{\mathrm{b}}$ & $0.80 \pm 0.01^{\mathrm{a}}$ \\
\hline
\end{tabular}

Mean \pm standard deviation; $n=4$; TE: Trolox Equivalent; FM: fresh matter. Averages on the same line followed by different letters have significant difference $(p<0.05)$.

Therefore, Method 2 had higher values of phenolics, flavonoids and antioxidant activity, thus, corroborating results found by other authors [4]. However, this comparison is important because the aqueous extraction is one of the most common forms of consumption by the population and involves low-cost reagents.

\section{DISCUSSION}

The pulp mass is the most important physical characteristic of the fruit in terms of economic use [25] (Table 1). The cerrado pear from Goiás had higher pulp yield $(64.35 \mathrm{~g}$ $\mathrm{kg}^{-1}$ ) than the one found in araticum $\left(45.9 \mathrm{~g} \mathrm{~kg}^{-1}\right)$ (Annona crassiflora Mart) [26]. Also, from a conservation point of view, the determination of acidity is an important factor in defining the durability of a product. The $\mathrm{pH}$ and titratable acidity that were found by this study corroborate what had already been reported by Donadio and Moro [7], who consider the cerrado pear an acid fruit that increases our durability. The TSS/TTA ratio provides better evaluation of the fruit flavor, since it is more representative than isolated measurements of sugar contents or acidity [27]. The TSS/TA ratio found by this study was $2.89 \pm 0.02$, similar to the one reported for Genipa americana L. fruits (2.04) [25].

The comparison of the proximal compositions of the cerrado pear and other fruits from the Cerrado biome shows that the moisture content of the cerrado pear is similar to the ones of cagaita (E. dysenterica DC.) and murici (Byrsonima crassifolia L. RICH) $\left(80.87 \mathrm{~g} \mathrm{~kg}^{-1}\right.$ and $93.12 \mathrm{~g} \mathrm{~kg}^{-1}$, respectively) [3,6]. Its protein content is similar to the ones of cagaita (0.60 and $0.63 \mathrm{~g} \mathrm{~kg}^{-1}$, respectively) [28,3] whereas its lipid content is similar to the ones of araticum and coquinho-azedo (Butia Capitata Mart.) (2.14 and $2.73 \mathrm{~g} \mathrm{~kg}^{-1}$, respectively) [29].

The cerrado pear has high fiber content, i. e., a portion of 100 grams of the fruit represents $25 \%$ of the daily requirement of dietary fiber recommended for an adult [30] Similar results were found by Bramorsk et al. [31] for camarinha (Gaylussacia brasiliensis) $\left(6.53 \mathrm{~g} \mathrm{~kg}^{-1}\right)$, a fact that shows the potential of Cerrado native fruits and their contribution to the nutritional value of the human diet. Fiber is important to human health because it has the ability to absorb water in the large intestine, increase intestinal motility and reduce the risk of colon problems, such as constipation and cancer. Besides, fiber reduces serum levels of triglycerides and glucose [32]. Besides, since $100 \mathrm{~g}$ of an edible portion had $96.07 \mathrm{kcal}$, the caloric value of the cerrado pear is considered high [33].

The pulp gave important contribution to the DRI of iron, manganese, copper, potassium, phosphorus, magnesium and zinc. The zinc content was found cerrado pear pulp showed to be close to what had been reported by Fidalski [34] for orange, a common fruit very consumed in the human diet. Its iron content $\left(16.5 \mathrm{mg} \mathrm{kg}^{-1}\right)$ was 55 -fold higher than the one reported for common pears $\left(0.30 \mathrm{mg} \mathrm{kg}^{-1}\right)$ [35]. Iron is an important mineral because it is responsible for the oxygen storage and use in the body blood [35]. 
As for the bioactive compounds the cerrado pear pulp presented low chlorophyll content, and carotenoid contents and vitamin C content important for human health. Low chlorophyll content found in the cerrado pear pulp was due to the maturation process, in which chlorophyll is degraded, thus, causing changes in the color of the pericarp to gradual extinction and increasing the synthesis or expression of carotenoid pigments [36]. Carotenoid contents of the cerrado pear pulp were $0.034 \mathrm{mg} \beta$-carotene $\mathrm{kg}^{-1}$ and $0.055 \mathrm{mg}$ lycopene $\mathrm{kg}^{-1} \mathrm{FM}$. In the human organism, $\beta$-carotene undergoes oxidation, resulting in two aldehydes called retinal, which are converted to Vitamin A by biochemical reactions [36]. Vitamin $\mathrm{C}$ content found by this study for the cerrado pear pulp was similar to the one reported by Park et al. [37] for pear $\left(8 \mathrm{mg} \mathrm{kg}^{-1}\right.$ ) (Pyrus communis). The intake of food containing vitamin $\mathrm{C}$ is required because of the important roles it plays in the human organism. Ascorbic acid acts as substrate in hydroxylation, wound healing, immune responses, nourishing the cells, and, therefore, essential to human metabolism. Besides, vitamin $C$ acts as an antioxidant and can prevent oxidative damage [38].

In both extraction methods studied, TPC content of the cerrado pear (333-566 mg EAG $\left.\mathrm{kg}^{-1}\right)$ was higher than the value reported by Rocha et al. [28] for acetone solution $70 \%(217$ $\mathrm{mg}$ EAG $\mathrm{kg}^{1}$ ). Thus, the cerrado pear had higher TPC than native fruits from the Cerrado, such as cagaita ( $111 \mathrm{mg} \mathrm{EAG} \mathrm{kg}^{-1}$ ), gabiroba (Campomanesia adamantium) (259 mg EAG $\mathrm{kg}^{-1}$ ), pitanga (Eugenia punicifolia) (327 mg EAG kg-1) [28] and uvaia (Eugenia pyriformis Cambess) (127 mg EAG kg-1) [39]. In the classification proposed by Vasco, Ruales and Kamal-Eldin [40], in both extraction methods, the cerrado pear is classified as medium TPC (100-500 mg EAG kg-1). Phenolic compounds are secondary metabolic products that are associated with mechanisms of adaptation and plant defense against ultraviolet rays, microorganisms and insects. Regarding human health, fruit and vegetable intake has been associated with low risks of chronic diseases. This effect is associated with polyphenols and their effects on the human organism [6].

Independent of the extraction methods, flavonoid contents found by this study were higher (225-550 mg EQ kg-1) than the ones reported by Nascimento et al. [41] for other species of Eugenia sp. (16 mg EQ kg-1). The intake of flavonoid-rich fruits is recommended because they increase the antioxidant capacity of the body and protect it against lipid peroxidation. Regarding flavonoids found in Brazilian fruits, the most frequently reported in literature are myricetin, quercetin and kaempferol.

The antioxidant activity by DPPH assay expressed in $\mathrm{EC}_{50}$ of the cerrado pear was more efficient that BHT (854 $\left.\mu \mathrm{g} \mathrm{mL}^{-1}\right)$, ascorbic acid $\left(4 \mu \mathrm{g} \mathrm{mL}^{-1}\right)$ and gallic acid $\left(2 \mu \mathrm{g} \mathrm{mL}^{-1}\right)$, which have been commonly used as antioxidants by the food industry. The antioxidant activity can be attributed to the presence of ascorbic acid, phenolic compounds and carotenoids, substances which have been confirmed as potent antioxidants [39].

The values of antioxidant activity by ABTS assay for two methods $(220.80-319.20 \mu \mathrm{mol}$ $\mathrm{TE} \mathrm{g}^{-1}$ ) were similar to the ones of guava (Psidium cattleyanum Sabine) $\left(242.30 \mu \mathrm{mol} \mathrm{ET} \mathrm{^{-1 }}\right)$

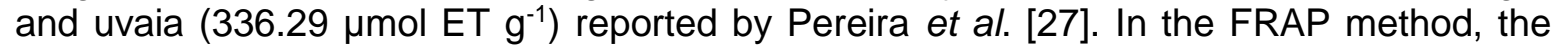
cerrado pear had $0.47 \mu \mathrm{M} \mathrm{Fe}^{2+} \mathrm{g}^{-1} \mathrm{FM}$ and $0.80 \mu \mathrm{M} \mathrm{Fe}^{2+} \mathrm{g}^{-1} \mathrm{FM}$ in Method 1 and Method 2, respectively. Similar values were found for Canarium odontophyllum fruits (0.27 and 1.74 $\left.\mu \mathrm{M} \mathrm{Fe} \mathrm{F}^{2+} \mathrm{g}^{-1} \mathrm{FM}\right)[42]$.

\section{CONCLUSION}

This study provides information about E. klotzschiana O. Berg fruits, which are unknown and unexplored in the Brazilian Cerrado. It contributes to develop knowledge and stimulate sustainable use of these fruits by the food industry and the population.

The cerrado pear showed that it has high nutritional value, mainly high fiber and iron contents. The cerrado pear proved that it is a very interesting fruit regarding its carotenoids, flavonoids, phenolic compounds, ascorbic acid compositions and, consequently, its antioxidant activity. Thus, the cerrado pear can be considered a good source of these compounds and can be consumed as a result of the sustainable use of the Cerrado biome. 
Funding: This research was funded by CNPq, grant number 426479/2016-5. This study was financed in part by the Coordenação de Aperfeiçoamento de Pessoal de Nível Superior - Brasil (Capes) - Finance Code 001.

Conflicts of Interest: The authors declare no conflict of interest. The funders had no role in the design of the study; in the collection, analyses, or interpretation of data; in the writing of the manuscript, or in the decision to publish the results.

\section{REFERENCES}

1. Myers, N.; Mittermeier, R.A; Mittermeier, C.G; Fonseca, G.A.B.; Kent, J. Biodiversity hotspots for conservation priorities. Nature 2000, 403, 853-858.

2. Kaur, C.; Kapoor, H.C. Antioxidants in fruits and vegetables - the millennium's health. Int J Food Sci Tech 2001, 36, 703-725.

3. Cardoso, L.M.; Martino, H.S.D.; Moreira, A.V.B.; Ribeiro, S.M.R.; Sant'Ana, H.M.P. Cagaita (Eugenia dysenterica DC.) of the Cerrado of Minas Gerais, Brazil: Physical and chemical characterization, carotenoids and vitamins. Food Res Int 2011, 44, 2151-2154.

4. Almeida, M.M.B.; Sousa, P.H.M.; Arriaga, A.M.C.; Prado, G.M.; Magalhães, C.E.C.; Maia, G.A.; Lemos, T.L.G. Bioactive compounds and antioxidant activity of fresh exotic fruits from northeastern Brazil. Food Res Int 2011, 44, 2155-2159.

5. Roesler, R.; Malta, L.G.; Carrasco, L.C.; Pastore, G. Evaluation of the antioxidant properties of the Brazilian Cerrado fruit Annona crassiflora (araticum). J Food Sci 2006, 71, 2.

6. Souza, V.R.; Pereira, P.A.P.; Queiroz, F.; Borges, S.V. Carneiro, J.D.S. Determination of bioactive compounds, antioxidant activity and chemical composition of Cerrado Brazilian fruits. Food Chem 2012, 134, 381-386.

7. Donadio, L.C.; Moro, F.V. Potential of brazilian Eugenia myrtaceae - as ornamental and as a fruit crop. Acta Hortic 2004, 632, 65-68.

8. Faria Junior, J.E.Q. O gênero Eugenia (Myrtaceae) nos estados de Goiás e Tocantins, Brasil. Master's thesis in Botanics. Universidade de Brasília, Brasília, 2010.

9. Ribeiro, J.F.; Silva, J.C.; Batmanian, G.J. Fitossociologia de tipos fisionômicos do Cerrado em Planaltina-DF. Rev Bras Botân 1985, 8, 131-142.

10. Zenebon, O.; Pascuet, N.S.; Tiglea, P. Métodos físico-químicos para análise de alimentos. Instituto Adolfo Lutz: São Paulo, Brazil, 2008; pp. 85-158.

11. Association of Official Analytical Chemists Official methods of analysis of the Association of Official Analytical Chemists - AOAC, 16rd ed; AOAC: Washington, Brazil, 2008.

12. Merril, A.L.; Watt, B.K. Energy value of foods: Basis and derivation, United States Department of Agriculture: Washington, US, 1973; pp. 105

13. Miller, G.L. Use of dinitrosalicylic acid reagent for determination of reducing sugar. Anal Chim 1959, 31, 426- 428.

14. Malavolta, E.; Vitti, G.C.; Oliveira, S.A. Avaliação do estado nutricional das plantas: princípios e aplicações, 2sd ed.; Potafos: Piracicaba, 1997, pp. 319.

15. Nagata, M. Yamashita, I. Simple method for simultaneous determination of chlorophyll an carotenoids in tomato fruit. J Japan Soc Food Sci Technol 1992, 39, 925-928.

16. Arnon, D.I. Copper enzymes in isolated chloroplasts polyphenoloxidase in beta vulgaris. Plant Physiol 1949, 24, 1-15.

17. Benassi, M.T.; Antunes, A.J. A comparison of meta-phosphoric and oxalic acids as extractant solutions for the determination of vitamin C in selected vegetables. Arq Biol Tech 1988, 31, 507-513. 18. Lima, C.A.; Faleiro, F.G.; Junqueira, N.T.V.; Cohen, K.O.; Guimarães, T.G. Características físico-químicas, polifenois e flavonoides amarelos em frutos de espécies de pitaias comerciais e nativas do cerrado. Rev Bras Frutic 2013, 35, 565-570.

19. Larrauri JA, Rupérez $P$ and Saura-calixto F. Effect of drying temperature on the stability of polyphenols and antioxidant activity of red grape pomace peels. J Agric Food Chem 1997, 45, 1390-1393.

20. Subhasree, B.; Baskar, R.; Laxmi keerthana, R.; Lijina Susan, R.; Rajasekaran, P. Evaluation of antioxidant potential in selected green leafy vegetables. Food Chem 2009, 115, 1213-1220.

21. Waterhouse, A.L. Polyphenolics: Determination of total phenolics. In Current Protocols in Food Analytical Chemistry; Wrolstad R.E., Ed., John Wiley \& Sons: New York, US, 2002; pp. I1.1.1-I1.1.8. 22. Brand-Williams, W.; Cuvelier, M.E.; Berset, C. Use of a free radical method to evaluate antioxidant activity. Food Sci Technol 1995, 28, 25-30.

23. Re, R.; Pellegrini, N.; Proteggente, A.; Pannala, A.; Yang, M.; Rice-Evans, C. Antioxidant activity applying an improved ABTS radical cation decolorization assay free radical. Biol Med 1999, 26, 1231-1237. 
24. Benzie, I.F.F.; Strain, J.J. The ferric reducing ability of plasma (FRAP) as a measure of antioxidant power: The FRAP assay. Anal Bioch 1996, 239, 70-76.

25. Hamacek, F.; Moereira, A.V.B.; Martino, H.S.D.; Ribeiro, S.M.R.; Pinheiro-Santana, H.M. Valor nutricional, caracterização física e físico-química de jenipapo (Genipa americana L.) do cerrado de Minas Gerais. Alim Nutr 2013, 24, 73-77.

26. Pimenta, A.C.; Rosa, P.S.; Zuffellato-Ribas, K.C.; Koehler, H.S. Caracterização de plantas e de frutos de araticunzeiro (Annnona crasssiflora Mart.) nativos no cerrado matogrossense. Rev Bras Frutic 2014, 36, 892-899.

27. Pereira, M.C.; Steffens, R.S.; Jablonski, A.; Hertz, P.F.; Rios, A.O.; Vizzotto, M.; Flores, S.H. Caracterization an antioxidant potential of Brazilian fruits from the Myrtaceae family. J Agric Food Chem 2012, 60, 3061-3067.

28. Rocha, W.S.; Lopes, R.M.; Silva, D.B.; Vieira, R.F.; Silva, J.P.; Agostini-Costa, T.S. Compostos fenólicos totais e taninos condensados em frutas nativas do cerrado. Rev Bras Frutic 2011, 33, 1215-1221.

29. Lopes, R.M.; Silva, J.P.; Vieira, R.F.; Silva, D.B.; Gomes, I.S. Composição de ácidos graxos em polpa de frutas nativas do cerrado. Rev Bras Frutic 2012, 34, 635-640.

30. Institute of Medicine. Food and Nutrition Board. Dietary Reference Intakes. National Academic Press, Washington D.C. (1999-2011)

31. Bramorski, A.; Cherem, A.R.; Mezadri, T.; Melo, S.S.; Deschamps, F.C.; Gonzaga, L.V.; Rochenbach II and Fett R. Chemical composition and antioxidante activity of Gaylussacia brasiliensis (camarinha) grown in Brazil. Food Res Int 2011, 44, 2134-2138.

32. Lai, T.N.H.; Andre, C.; Rogez, H.; Mignolet, E.; Nguyen, T.B.T.; Larondelle, Y. Nutritional composition an antioxidant property of the sim fruit (Rhodomyrtus tomentosa). Food Chem 2015, 168, 410-416.

33. Brasil. Resolução - RDC no 54, de 12 de novembro de 2012. Dispõe sobre o Regulamento Técnico sobre Informação Nutricional Complementar. Diário Oficial da União 19 nov. 2012.

34. Fidalski, J.; Auler, P.A.M.; Tormem, V. Relations among Valencia orange yields with soil and leaf nutrients in northwestern Paraná, Brazil. Braz Arch Biol Technol 2000, 43, doi: 10.1590/S1516-89132000000400006.

35. USDA-ARS (US Department of Agriculture, Agricultural Research Service) USDA nutrient database for standard reference, Release 25, Software 1.2.2, from the Nutrient Data Laboratory Page on the World Wide Web. 2015. http://www.nal.usda.gov/fnic/foodcomp [7 October 2016].

36. Schoefs, B. Chlorophyll and carotenoid analysis in food products. Properties of the pigments and methods of analysis. Trends Food Sci Technol 2002, 13, 361-371.

37. Park, Y.I.M.H.; Ham, K.; Kang, S.; Park, Y.N.J.; Leontowicz, H.; Leontowicz, M.; Trakhtenberg, S.; Gorinstein, S. Quantitative assessment of the main antioxidant compouns, antioxidant activities and FTIR spectra from commonly consumed fruits, compared to standard kiwi fruit. Food Sci Technol 2015, 63, 346-352.

38. Oliveira, M.C.; Schoffen, J.P.F. Oxidative Stress Action in Cellular Aging. Braz Arch Biol Technol 2010, 55, 1333-1342.

39. Rufino, M.S.M.; Alves, R.E.; Brito, E.S.; Pérez-Jiménez, J.; Saura-Calixto, F.; Mancini-Filho, J. Bioactive compounds and antioxidant capacities of 18 non-traditional tropical fruits from Brazil. Food Chem 2010, 121, 996-1002.

40. Vasco, C.; Ruales, J.; Kamal-Eldin, A. Total phenolic compounds and antioxidant capacities of major fruits from Ecuador. Food Chem 2008, 111, 816-823.

41. Nascimento, V.T.; Moura, N.P.; Vasconcelos, M.A.S.; Maciel, M.I.S.; Albuquerque, U.P. Chemical characterization of native wild plants of dry seasonal forests of the semi-arid region of northeastern Brazil. Food Res Int 2011, 44, 2112-2119.

42. Chew, L.Y.; Nagendra, P.; Amin, I.; Azrina, A.; Lau, C.Y. Nutritional composition and antioxidant properties of Canarium odontophyllum Miq (dabai) fruits. J Food Comp Anal 2011, 24, 670-677.

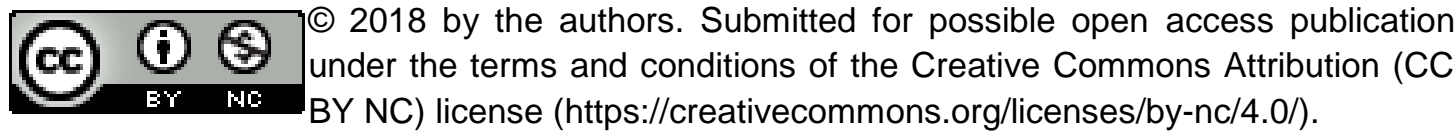

